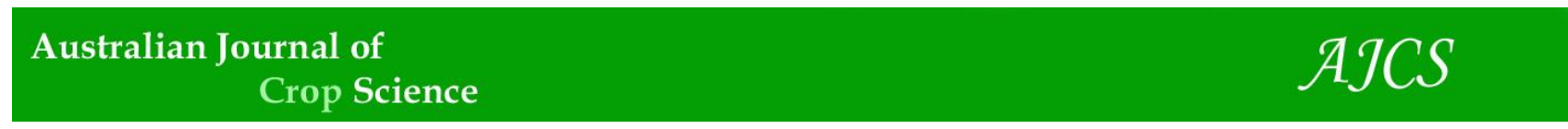

AJCS 11(07):868-873 (2017)

ISSN:1835-2707

doi: 10.21475/ajcs.17.11.07.pne513

\title{
Mechanisms of resistance to metribuzin in new resistant biotype of jungle rice (Echinochloa colona) in sugarcane fields of hot semi-arid climates
}

\author{
Majid Nabipour", Seyed Reza Ahmadpour, Musa Mesgarbashi, Hamid Rajabi-Memari, Masume \\ Farzane
}

Agronomy and Plant Breeding Department, Faculty of Agriculture, Shahid Chamran University of Ahvaz, Iran

*Corresponding author: nabipourm@yahoo.com

\begin{abstract}
The practice of monoculture and the use of one-mode-action herbicides for more than 10-year period can cause development of resistant jungle rice [(Echinochloa colona (L.)] to photosystem II inhibitors. Jungle rice is one of the most troublesome weeds in the sugarcane fields of Iran. Laboratory and greenhouse testing was carried out from 2013 to 2016 to investigate the development and determine the origin of metribuzin-resistant jungle rice biotypes in the sugarcane fields of Khuzestan province. Five populations of jungle rice ( 1 susceptible and 4 suspected resistant) were collected and assayed. The suspected populations were first screened using discriminating concentrations of mertibuzin. To determine the resistance factor for R-biotypes, bioassay trials were conducted in a greenhouse. Then, PCR sequencing markers used in the laboratory and PCR products were subjected to pair-end sequencing by Eurofins Scientific to determine the molecular base of resistance in the R-biotypes. The results of seedling bioassays showed that four biotypes were resistant to metribuzin. The weed control efficiency of metribuzin for the R4, R2, R3 and R1 biotypes were $12.38 \%, 27.24 \%, 59.29 \%$ and $75.21 \%$, respectively. The resistance factor for the R4 and R2 biotypes were 58.51 and 30.23 respectively; ranking these as resistant biotypes. Gene sequencing studies found an effective mutation at position 232 of the psbA gene that resulted in amino acid substitution from Serine to Glycine at residue 264 in the D1 protein in R-biotypes versus S-biotypes. These results show that target site resistance to metribuzin is rapidly developing in sugarcane fields in northern Khuzestan province. This could stem from the spread of resistant biotype seeds through irrigation water from the Karun Agro-industry fields (first reported sites of resistance) or by herbicide selection pressure.
\end{abstract}

Keywords: Gene sequencing, Photosynthesis, Photosystem II, Point mutation, psbA gene.

Abbreviations: D1_a protein; $\mathrm{EC}_{50}$ effective concentration; $\mathrm{ED}_{50}$ effective dose; psbA_photosystem II protein D1 gene (accession no.: AFZ76983.1); R-biotypes_resistant biotypes; $\mathrm{Rf}_{50 \_}$resistance factor; Metribuzin_4-amino-6-tert-butyl-3-(methylthio)-as-triazin5(4H)-one; S-biotypes_susceptible biotypes.

\section{Introduction}

Herbicide resistance can result from a lack of diversity in weed management (Shaner and Beckie, 2014). Herbicide resistance is a global problem that threatens sustainable agriculture. There are currently 473 unique cases (species $x$ site of action) of herbicide resistant weeds globally, with 251 species (146 dicots and 105 monocots). Weeds have evolved resistance to 23 of the 26 known herbicide sites of action and to 160 different herbicides (Gherekhloo et al., 2016; Heap, 2016). SII inhibitors were the first herbicide groups imported to Iran and have a long history of application in farms. They are classified as of intermediate resistance risk with the chance of resistance development increasing substantially after 11 years of continuous usage (Beckie and Reboud, 2009). PSII inhibitors such as atrazine, chloridazon, propanil and metribuzin have a 40-year history of application in sugar beet and sugarcane fields, but had not exhibited signs of resistance until 2013 in Iran. The incidence was first reported by Elahifard et al. (2013b). Triazine and triazinone herbicides (group $\mathrm{C}_{1}$ ) have a moderate-to-high risk of selection for resistance (Beckie, 2006; Beckie and Tardif, 2012). These herbicides inhibit photosynthesis in susceptible plants by blocking the transfer of electrons from QA (electron donor) to QB (mobile electron carrier) (Tharayil-Santhakumar, 2003). Their function is the biochemical displacement of the plastoquinone $(\mathrm{PQ})$ binding site on the $\mathrm{D} 1$ protein in the PS II reaction center of the photosynthetic electron transport chain (Abbaspoor and Streibig, 2007). The most common mechanism of resistance to triazine herbicides has been reported in more than six cases. It is a mutation in the psbA gene which encodes the D1 protein that alters the site of the protein at which triazine and triazinone binding occurs (Menendez et al., 2007; Beckie and Tardif, 2012; Park and Mallory-Smith, 2006; Perry et al. 2012). In most cases, a Ser264-to-Gly mutation in the D1 protein (psbA gene) is responsible for conferring resistance onto weed biotypes (Devine and Shukla, 2000). Mutations such as Val219-to-Ile, Ser264-to-Thr, Asn266-to-Thr, Phe255-to-Ile and Ala251-toVal have reported psbA gen as the site of resistance to the photosystem II inhibitor herbicide group. The highest levels of resistance in triazine and triazinone herbicides were reported for Ser264-to-Gly, Ser264-to-Thr and Ala251-to-Val mutations (Perry et al. 2012). DNA sequence analysis of the psbA gene, which is the target site of PSII inhibiting herbicides, revealed two nucleotide changes (A to $G$ ) at loci 232 and 286 had conferred substitutions of amino acids from serine to glycine at residue 264 in the resistant biotypes of $E$. Colona Complementary testing uncovered cross-resistance 
development in the E. colona populations to ametryn and metribuzin.(Elahifard et al., 2013a).

Biotypes containing this mutation exhibit a resistance factor of 1000 at the binding site on the D1 protein and 100 for the whole plant level (Fuerst et al., 1986). Resistance mutations can occur at the locus, except for Ser264, and mutations at Ser264 do not necessarily confer herbicide resistance (Gronwald, 1994; Devine and Eberlein, 1997; Ernst et al., 1996). Several mutations at locus (except Ser264) have been identified that confer resistance to triazine herbicides (Mengistu et al., 2000).

Sugarcane (Saccharum officinarum L.) has been monocropped in Khuzestan province for over three decades. Continuous and intensive application of PSII inhibitors has increased the probability of resistance development (Zand et al., 2007). Elahifard et al. (2013a) reported resistance of jungle rice (Echinochloa colona (L.) Link) populations to triazine and triazinone herbicides in the sugarcane fields of northern Khuzestan province. Reports from other new canegrower agro-industries indicate that resistance to triazine and triazinone are rapidly developing in southern Khuzestan. Because of the previous use of metribuzin in these fields, there are questions about the origin of resistance and the reasons for its development. The aims of the present research were to investigate the development of resistance to triazinone herbicides, evaluate the origin of new resistant biotypes and determine their resistant mechanisms and utilize these new findings to develop better strategies for weed management.

\section{Results and Discussion}

\section{Biotype screening by the discriminator doses}

Moss et al. (2007) reported that fresh seedling weight is a suitable indicator when screening biotypes suspected of resistance and this approach was used in the present study. They classified the biotypes into four groups according to percentage of decrease in fresh weight as: $0 \%$ to $36 \%, 37 \%$ to $72 \%, 73 \%$ to $81 \%$ and $82 \%$ to $100 \%$. These were denoted as RRR (resistance confirmed, highly likely to reduce herbicide performance), RR (resistance confirmed, likely to reduce herbicide performance, $\mathrm{R}$ (early indications that resistance may be developing) and $\mathrm{S}$ (susceptible), respectively.

The biotypes in this experiment showed different responses to the discriminator doses (Table 1). Sc13-30(R1) and Sc325(R2) biotypes showed the lowest percentage of decrease in seedling fresh weight compared to the control $(12.38 \%$ and $27.24 \%$, respectively), the smallest decrease in plant number ( $8 \%$ and $16 \%$, respectively) compared to the control and visual assessments of $21.43 \%$ and $35 \%$ compared to the control; these were categorized as RRR. The P1-6 biotype with a $59.29 \%$ decrease in seedling fresh weight compared to the control, $36 \%$ decrease in plant number compared to the control and visual assessment of $50.3 \%$ was categorized as RR. Sc7-1 showed a $75.21 \%$ decrease in fresh weight compared to the control, a $86.5 \%$ decrease in plant number compared to the control and the greatest injury upon visual assessment and was categorized as R.

The R4-11 biotype (control) showed considerable sensitivity to the discriminator dose, the greatest injury from herbicide application according to visual assessment, the greatest decrease in plant number and in fresh weight compared to the control and was categorized as S to PSII inhibitor herbicides.
Bioassay in greenhouse by dose-response curve (determination the resistance grade)

The results indicate that application of $49.88 \mathrm{~g}$ ai/ha of herbicide to the sensitive biotype (R4-11) caused 50\% inhibition $\left(\mathrm{ED}_{50}\right)$ of fresh weight. To cause $50 \%$ inhibition of the Sc13-30, Sc3-23, P1-6 and Sc7-1 biotypes required the application of metribuzin at 2918.5, 1508.058, 367.48 and $90.79 \mathrm{~g}$ ai/ha respectively (Table 2; Fig 1).

The RF of Sc13-30, Sc3-25, P1-6 and Sc7-1 biotypes were $58.51,30.23,7.36$ and 1.82 , respectively. These results and the results of screening confirm that there are genetic and molecular differences among these biotypes. Table 2 shows that Sc13-30 and Sc3-25 biotypes had the highest level of resistance in the no-herbicide condition and the lowest fresh weight among the studied biotypes. The control R4-11 biotype sensitive (control) recorded a maximum fresh weight in the no-herbicide condition. This difference could be the result of genetic changes in these biotypes and expression of resistance genes.

\section{Comparing pabA gene sequence in $S$ and $R$-biotypes}

The DNA sequence analysis of the pabA gene identified a 342-bp region which encoded 211-300 amino acid residues in D1 protein. More than 30 single nucleotide differences were identified between the $\mathrm{R}$ and S-biotypes. Most produced no change in the encoded amino acid sequence; however, the nucleotide change (A to $\mathrm{A} / \mathrm{G}$ ) at locus 232 provided an amino acid substitution from serine to glycine in the $\mathrm{R}$ biotypes. Note that these loci correspond to amino acid codon 264, one of the most common amino acid substitutions conferring triazine and triazinone resistance in plants (Perry et al., 2012). The same sequence in four R-biotypes (R1, R2, R3, R4) exhibited a Ser264-to-Gly substitution in the psbA gene (Fig. 2).

This change in the amino acid could make a significant difference in the structure of the protein because serine is a polar amino acid while glycine is not. These results confirm the results of Tian and Darmency (2006), Park and MallorySmith (2006) and Elahifard et al. (2013a), with a slight difference from Elahifard et al. (2013a) in S-biotype sequencing. They reported a serine-to-glycine substitution in codon 282 in addition to the 232 position but the results of the present study found no such substitution at the 282 site for the S and R biotypes. Uniport Gene banks were checked for this gene sequence in Echinochloa spp., but no difference in the present results from Ye et al. (2014), Nah et al. (2016) and Perumal et al. (2016) for S-biotype sequencing in 282 codon was found. It is believed that this could be a mistranslation occurring in Elahifard et al. (2013a) when reading Ser amino acid in codon 282 in susceptible biotypes. The first resistant biotypes of $E$. colona to PSII inhibitor herbicides were observed in the fields of Karun Agroindustry in Shoushtar in northern Khuzestan province $\left(32^{\circ} 04^{\prime} 32.8^{\prime \prime} \mathrm{N}, 48^{\circ} 40^{\prime} 36.2^{\prime \prime} \mathrm{E}\right)$. This location had a more than 30-year history of application of PSII inhibitor herbicides (triazine and triazinone). In the present study, the site of seed collection had a history of less than 11 years of metribuzin use.

Analysis of satellite images show that the resistant seed collected from the present study is near the location of the first report of this species in the Khuzestan province (Fig. 3). This confirms the theory about one location of origin for resistance in the experimental area. The results of gene sequencing of biotypes conducted by Elahifard et al. (2013a) indicate that, in both studies, changes in amino acid 264 (the 
Table 1. Results of biotype screening after herbicide application at discriminator dose.

\begin{tabular}{lcccccc}
\hline Biotype & $\begin{array}{c}\text { Decrease in } \\
\text { fresh weight } \\
(\%)\end{array}$ & $\begin{array}{c}\text { Decrease in } \\
\text { dry weight } \\
(\%)\end{array}$ & $\begin{array}{c}\text { Visual } \\
\text { assessment }\end{array}$ & $\begin{array}{c}\text { Decrease in plant } \\
\text { number } \\
(\%)\end{array}$ & RF & $\begin{array}{c}\text { Susceptibility to } \\
\text { herbicide }\end{array}$ \\
\hline R4-11(S) & 95.93 & 93.18 & 98.8 & 100 & - & S \\
Sc7-1(R1) & 75.21 & 71.13 & 86.5 & 56 & 1.82 & R \\
Sc3-25(R2) & 27.24 & 42.76 & 35 & 16 & 30.23 & RRR \\
P1-6(R3) & 59.29 & 66.3 & 50.3 & 36 & 7.36 & RR \\
Sc13-30(R4) & 12.38 & 21.43 & 20 & 8 & 58.51 & RRR \\
\hline
\end{tabular}

S: susceptible

RRR : resistance confirmed, highly likely to reduce herbicide performance

$\mathrm{RR}$ : resistance confirmed, likely to reduce herbicide performance

R: early indications that resistance may be developing, possibly reducing herbicide performance.

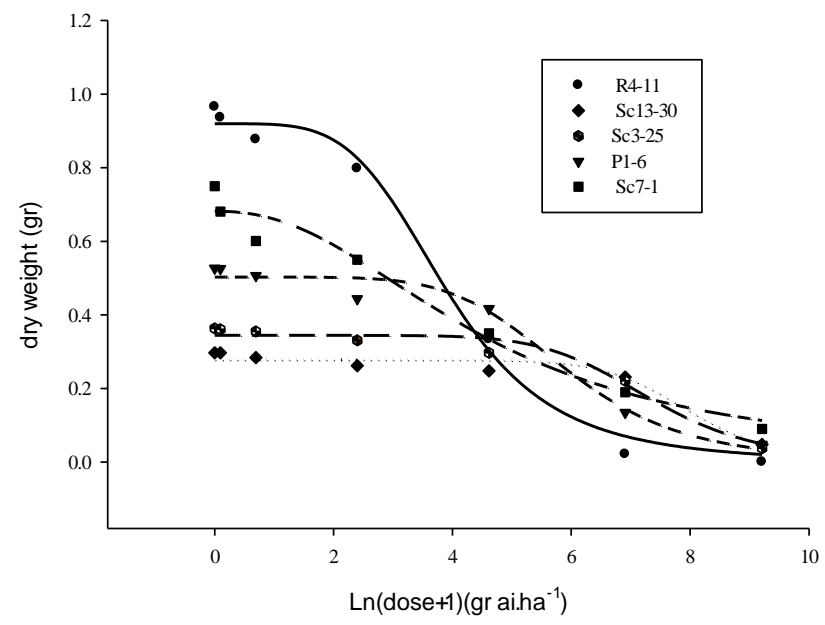

Fig 1. Dose response curve of studied biotypes (logistic 3-parameter equation fitted to data $\operatorname{Ln}(x+1)$ transformation was used to drag the curve).

Table 2. Estimated parameters of logistic 3-parameter equation fitted to bioassay of biotypes.

\begin{tabular}{lcccc}
\hline Biotype & upper limit & slope & ED $_{50}$ & Radj \\
\hline R4-11(S) & $0.919( \pm 0.026)$ & $4.41( \pm 0.81)$ & $49.88( \pm 0.21)$ & 0.98 \\
Sc7-1(R1) & $0.681( \pm 0.03)$ & $2.27( \pm 0.5)$ & $90.79( \pm 0.47)$ & 0.95 \\
Sc3-25(R2) & $0.344( \pm 0.01)$ & $7.82( \pm 2.27)$ & $1508.06( \pm 0.27)$ & 0.95 \\
P1-6(R3) & $0.503( \pm 0.01)$ & $5.87( \pm 1.24)$ & $367.48( \pm 0.28)$ & 0.97 \\
Sc13-30(R4) & $0.277( \pm 0.009)$ & $10.8( \pm 2.72)$ & $2918.5( \pm 0.29)$ & 0.93 \\
\hline
\end{tabular}

$\mathrm{ED}_{50}$ : Effective dose that cause $50 \%$ of the inhibition in dry weight of population
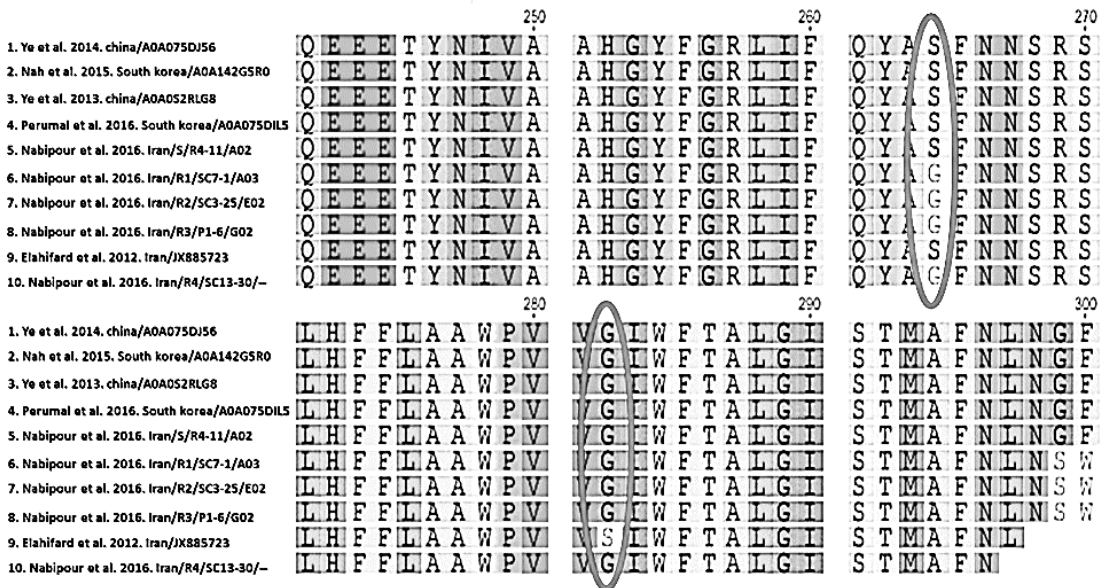

Fig 2. Comparison of R (nos. 6-8 and 10) and S (nos. 1-5 and 9) biotype sequences for psbA gene in Echinochloa spp. 


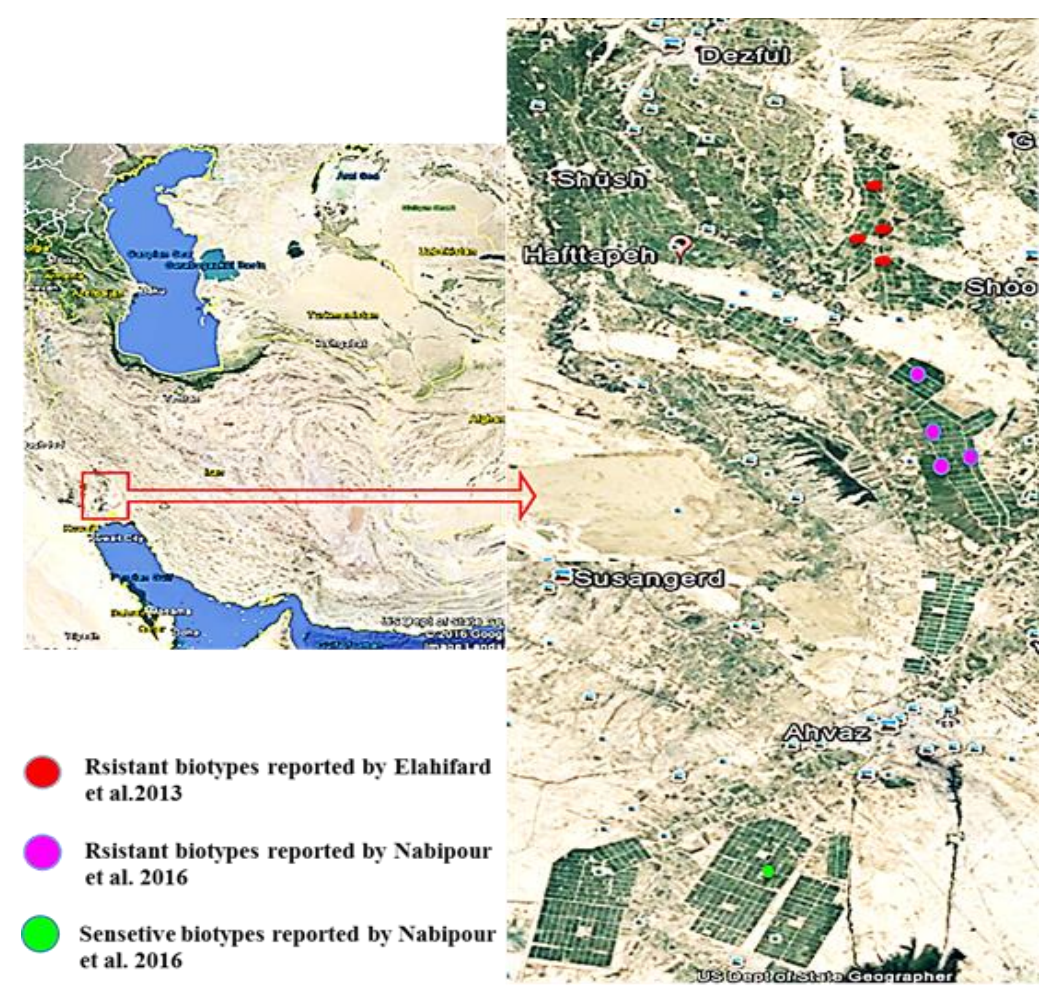

Fig 3. Dispersal map of biotypes to resistant to metribuzin (PSII inhibitor herbicides).

most sensitive locus of D1 protein) caused substitution of serine by glycine amino acid in the resistant biotypes. This tructural change plays an important role in the development of resistance (Tian and Darmancy, 2006; Preston, 2009). Additionally, Ahmadpour et al. (2007) showed the highest amount of weed seeds collected from the Karun River belongs to this species. The contamination of Karun River, which provides water to irrigate both regions with this weed seed in summer can spread an average of 10 jungle seeds per ha during every irrigation period to every field. It is evident that irrigation is a major factor in resistant seed dispersal to new areas. It is evident that irrigation is a major factor in resistant seed dispersal to new areas. Several studies have reported that jungle rice can produce as many as 42000 seeds per plant per year (Peerzada et al. 2016). With the mass application of PSII inhibitor herbicides in many crops in this province, it is predictable that in the near future, resistance to PSII inhibitor herbicides will appear in more regions of province, especially in the sugarcane fields.

\section{Materials and Methods}

\section{Site of experiment}

This study was conducted at the Sugarcane and Byproduct Research and Training Institute of Khuzestan $\left(31^{\circ} 05^{\prime} 18.4 \mathrm{~N}\right.$ $\left.48^{\circ} 21^{\prime} 53.8^{\prime \prime} \mathrm{E}\right)$ and in Shahid Chamran University of Ahvaz (31 $\left.18^{\prime} 34.6^{\prime \prime} \mathrm{N} 48^{\circ} 39^{\prime} 27.3 " \mathrm{E}\right)$.

\section{Plant material and Seed source}

When collecting the seeds of jungle rice, the fields selected had a greater than 10-year history of application of metribuzin and the control of this weed by application of herbicide in these fields had decreased. The jungle rice plants in these areas were denoted as suspected of resistance. Susceptible seeds (control) were collected from fields with no history of application of this herbicide (Suppl. Table 1). The seeds were stored at room temperature $\left(25^{\circ} \mathrm{C}\right)$ in the dark before the experiments.

\section{Breaking seed dormancy}

Seed dormancy was broken by treatment with $96 \%$ sulfuric acid for $3 \mathrm{~min}$, they were then rinsed with distilled water.

\section{Screening suspected resistance biotypes}

To screen the collected biotypes, a factorial experiment in a randomized complete block design ( 5 biotypes $\times 2$ levels of herbicide application) was conducted in five replications in a greenhouse using either zero or the recommended dosage ( 2 $\mathrm{kg} / \mathrm{ha}$ ) of metribuzin. Five seedlings of each biotype were planted in $10 \times 15 \mathrm{~cm}$ pots filled with loam $(15.4 \%$ clay, $39.3 \%$ silt and $45.3 \%$ sand). Herbicide was applied was at the 2-4-leaf stage using a Matabi electric sprayer and flood-jet nozzles. Visual assessment scoring to herbicide injury included vital seedling ratio and percentage of fresh weight reduction in accordance with the European Weed Research Council standards (Sandral et al., 1997) using equations (1) and (2). Calculation of the vital seedling ratio to untreated control (same biotype) was calculated (equation (1)) and the seedling weight was measured at day 14 after application of the herbicide to compute the percentage of decrease in fresh weight compared to the untreated controls (same biotype) (equation (2)).

$\mathrm{Y}=\frac{\mathrm{N} 1}{\mathrm{~N} 0} \times 100$

Equation 1

where $\mathrm{Y}$ is the percentage of vital seedlings after herbicide application, N1 is the number of vital seedlings after herbicide application and N0 is the number of seedlings before herbicide application. 
Equation 2.

$\mathrm{Y}=\frac{\mathrm{Wt}}{\mathrm{wc}} \times 100$

where $Y$ is the percentage of decrease in fresh weight of vital seedlings after herbicide application compared to the untreated control seedlings, Wt is the fresh weight of the vital seedlings after herbicide application and $\mathrm{Wc}$ is the fresh weight of the untreated control seedlings.

\section{Bioassay in greenhouse using dose-response curve} (determination of resistance factor)

For the bioassays, the biotypes were planted as done in the screening step. Then herbicide was applied by a Matabi electrical sprayer and flood-jet nozzles at dosages of $0,0.01$, $1,10,100,1000$ and $10000 \mathrm{~g}$ ai/ha. At 2 wk post-application, the seedlings were weighed to obtain the fresh weight. To estimate the changes in fresh weight as affected by dosage of herbicide, the logistic 3-parameter equation (equation (3)) was used and the resistance factor of the biotypes was calculated using equation (4).

$$
\mathrm{Y}=\frac{\mathrm{a}}{1+\left(\frac{\mathrm{x}}{\mathrm{x}_{0}}\right) 0^{\mathrm{b}}}
$$

Equation 3

where $\mathrm{Y}$ is the fresh weight at dose $\mathrm{x}$, $\mathrm{a}$ is the upper limit of the curve, $\mathrm{X}$ is the herbicide dose, $\mathrm{X}_{0}$ is the dose of herbicide that causes a $50 \%$ decrease in fresh weight $\left(\mathrm{ED}_{50}\right)$ and $\mathrm{b}$ is the slope of the curve at point $\mathrm{X}_{0}$.

$\mathrm{RF}=\frac{\operatorname{Ed} 50(\mathrm{R})}{\operatorname{Ed} 50(\mathrm{~S})}$

Equation 4

where RF is the resistance factor of the biotype, $\operatorname{Ed}_{50}(\mathrm{R})$ is the dose of herbicide that causes $50 \%$ inhibition of the resistant biotype, $\operatorname{Ed}_{50}(\mathrm{~S})$ is the dose of herbicide that caused $50 \%$ inhibition of the sensitive biotype.

\section{Gene sequencing}

DNA sequencing was used to identify the molecular basis of resistance. Leaf tissue (about $150 \mathrm{mg}$ ) from a plant of each jungle rice biotype was used for DNA extraction using the optimized methods described by Doyle and Doyle (1987).

The region of the psbA gene (accession no.: AFZ76983.1) in the template DNA was amplified using PCR. The forward and reverse primers utilized were psbA $F$ : 5'ATCGGTCAAGGAAGCTTTTC-3' and R: 5'AACCGTTTAGGTTGAAAGCC-3' (Foes et al. 1998). Amplification of the psbA gene for each plant was carried out as a separate reaction. The amplification reaction contained $\sim 25$ ng of total DNA, $0.4 \mu \mathrm{M}$ each of two primers, 1 unit of Taq DNA polymerase (Cinnagen; Iran), $1 \mathrm{mM} \mathrm{Mgcl}, 0.25$ $\mathrm{mM}$ dNTPs and $2.5 \mu \mathrm{l}$ PFU buffer (10x) to a final volume of $25 \mu \mathrm{l}$. These reactions were incubated for $4 \mathrm{~min}$ at $94^{\circ} \mathrm{C} ; 40$ cycles of $0.5 \mathrm{~min}$ at $94^{\circ} \mathrm{C}, 0.5-\mathrm{min}$ at $50^{\circ} \mathrm{C}$ and 0.75 -min at $72^{\circ} \mathrm{C}$; and $5 \mathrm{~min}$ of incubation at $72^{\circ} \mathrm{C}$. The PCR products were fractioned through $1.2 \%$ agarose gel and SB (1x) buffer. DNA Safe Stain (Cinnagen; Iran) was used to dye the gel. PCR products were sequenced by Eurofins Scientific and analyzed using Sequencer software (Geneious 8.0.5).

\section{Statistical analysis}

The software used in this study were Microsoft Office Excel ver. 2013, Geneious ver. 8.0.5 and SigmaPlot ver. 12.2.

\section{Conclusion}

This study showed that reason for resistance to metribuzin in biotypes of jungle rice is mutation in locus 264 of resistant biotypes which induces substantial structural changes in the D1 protein. In addition to the possibility of development of resistance through herbicide selection pressure, resistant biotypes in older fields may be spreading their seeds via irrigation water from the Karun River. The high speed of the spread of identical resistant biotypes confirms an single origin of the different seeds in various regions of Khuzestan province. Along with increased research in other regions and monitoring of the status of resistance to such herbicides, it is essential to alter the application of PSII inhibitor herbicides, especially in northern regions to prevent the development resistance in other fields. The use of integrated weed management, rotation of herbicides with different modes of action, compliance with quarantines for farms suspected of resistance and transmission of resistant jungle rice seeds from infected farms to other farms should be avoided.

\section{Acknowledgements}

The authors would like to thank the Sugarcane Development and Byproducts Research and Training Institute for financial support of this research.

\section{References}

Abbaspoor M, Streibig JC (2007) Monitoring the efficacy and metabolism of phenylcarbamates in sugar beet and black nightshade by chlorophyll fluorescence parameters. Pest Manag Sci. 63: 576-585.

Ahmadpour et al. (2007) Collection and measurement of weed seeds in Irrigation water of sugarcane fields in Khuzestan prov. Annual report. ISCRTI. 5:113-116.

Beckie HJ (2006) Herbicide-Resistant Weeds: Management Tactics and Practices. Weed Technol. 20:793-814.

Beckie HJ, Reboud X (2009) Selecting for weed resistance: herbicide rotation and mixture. Weed Technol. 23:363-370.

Beckie HJ, Tardif FJ (2012) Herbicide cross resistance in weeds. Crop prot. 35:15-28.

Devine MD, Eberlein CV (1997) Herbicide Activity: Toxicology, Biochemistry and Molecular Biology. in: Michael RR, Burton JD, Kuhr RJ. IOS Press, 1997. Amsterdam, pp. 159-164.

Devine MD, Shukla A (2000) Altered target sites as a mechanism of herbicide resistance. Crop Prot. 19: 881-889.

Doyle JJ, Doyle JL (1987) A rapid DAN isolation procedure for small quantities of fresh leaf tissue. Phytochem Bull. 19: 11-15.

Elahifard E, Ghanbari A, Rashed-Mohassel MH, Zand E, Kakhki AM, Mohkami A (2013a) Characterization of triazine resistant biotypes of Jungle-rice [Echinochloa colona (L.) Link.] found in Iran. Aust J Crop Sci. 7:13021308

Elahifard E, Ghanbari A, Rashed-Mohassel MH, Zand E, Kakhki AM, Abbaspoor M (2013b) Measuring chlorophyll fluorescence parameters for rapid detection of Ametryn resistant Jungle-rice [Echinochloa colona (L.) Link.]. Plant Knowl J. 2: 76-82.

Ernst D, Kiefer E, Bhler M, Bogenrieder A, Sandermann Jr (1996) On the basis of atrazine resistance in weeds. In: De Prado R, Jordin J, Torres LG, Marshall G (eds), Proceedings of the International Symposium on Weed and Crop Resistance to Herbicides. Gracas TYPO, Cordoba, Spain, 1996. pp. 56-59. 
Foes MJ, Liu L, Tranel PJ, Wax LM, Stoller EW (1998) A biotype of common waterhemp (Amaranthus rudis) resistant to triazine and ALS herbicides. Weed Sci. 46: 514-520.

Fuerst EP, Arntzen CJ, Pfister K, Penner D (1986) Herbicide cross-resistance in triazine-resistant biotypes of four species. Weed Sci. 34:344-353

Gherekhloo J, Oveisi M, Zand E, De-Prado R (2016). A review of herbicide resistance in Iran. Weed Sci. 64:551561

Gronwald J W (1994) Resistance to photosystem II inhibiting herbicides. In: Powles SB, Holtum JAM. (eds), Herbicide Resistance in Plants: Biology and Biochemistry. CRC Press, Boca Raton, FL, pp. 27-60.

plant sci, 7:169.

Heap I (2016) The International Survey of Herbicide Resistant Weeds. http://www.weedscience.org.

Menendez JA, Lupu R (2007) Fatty acid synthase and the lipogenic phenotype in cancer pathogenesis. Nat Rev Cancer, 7:763-777.

Mengistu LW, Mueller-Warrant GW, Barker RE (2000) Genetic diversity of Роа аппиа in western Oregon grass seed crops. Theor Appl Genet, 101:70-79.

Moss SR, Perryman SA, Tatnell LV (2007) Managing herbicide-resistant blackgrass (Alopecurus myosuroides): theory and practice. Weed Technol. 21:300-309.

Nah G, Im JH, Kim JW, Park HR, Yook MJ, Yang TJ (2015) Uncovering the Differential Molecular Basis of Adaptive Diversity in Three Echinochloa Leaf Transcriptomes. PLoS ONE 10: e0134419.

Park KW, Mallory-Smith CA (2006) psbA mutation (Asn266 to $\mathrm{Thr}$ ) in Senecio vulgaris $\mathrm{L}$. confers resistance to several PS II-inhibiting herbicides. Pest manag sci, 62:880-885.
Peerzada AM, Bajwa AAh, Ali HH, Chauhan BS (2016) Biology, impact, and management of Echinochloa colona (L.). Crop Prot. 83:56-66

Perry DH, McElroy JS, Dane F, Van Santen E, Walker RH (2012) Triazine-resistant annual bluegrass (Роа аппиа) populations with Ser264 mutation are resistant to amicarbazone. Weed Sci. 60: 355-359.

Perumal S, Jayakodi M, Kim DS, Yang Tj, Natesan S (2016) The complete chloroplast genome sequence of Indian barnyard millet, Echinochloa frumentacea (Poaceae). Mitochondr DNA. 1: 79-80.

Preston C (2009) Herbicide resistance: target site mutations. In: Stewart CN (eds) Weedy and invasive plant genomics, 1rd end. Wiley-Blackwell, New York.

Sandral GA, Dear BS, Pratley JE, Cullis BR (1997) Herbicide dose rate response curves in subterranean clover determined by a bioassay. Anim Prod Sci. 37: 67-74.

Shaner DL, Beckie HJ (2014) The future for weed control and technology. Pest manag sci. 70:1329-1339.

Tharayil-Santhakumar N (2003) Mechanism of herbicide resistance in weeds. Plant and Soil Science University of Massachusetts Amherst, MA., http://www. weedresearch. com/paper/Mechanism. 20 ppt.

Tian X, Darmency H (2006) Rapid bidirectional allelespecific PCR identification for triazine resistance in higher plants. Pest Manag Sci. 62:531-536.

Ye CY, Lin Z, Li G, Wang YY, Qiu J, Fu F, Jin G (2014) Echinochloa chloroplast genomes: Insights into the evolution and taxonomic identification of two weedy species. Plos Genet. 9:e113657.

Zand E, Baghestani MA, Bitarafan M, Shimi P (2007) A guideline for herbicides in Iran. Jihad-e-Daneshgahi Press. $66 \mathrm{pp}$. 